\title{
Infallible or Final?: Revisiting the Legitimacy of the International Court of Justice as the "Invisible" International Supreme Court
}

\author{
Neil B. Nucup \\ Universiteit Leiden \\ neil.nucup@icloud.com
}

\begin{abstract}
With the anarchic multiplication of international courts and tribunals, and the concomitant possibility for jurisdictional and decisional conflicts among them to occur, treating the International Court of Justice as the "invisible" international supreme court seems an attractive solution. After all, it is the principal judicial organ of the United Nations and the only court with universal general jurisdiction. Revisiting this proposal, the article argues that the World Court suffers not only from political (extrinsic) constraints, but also from institutional (intrinsic) limitations, thereby endangering its sociological and normative legitimacy. Nonetheless, this does not mean rectifying them for the purpose of enabling it to discharge its envisioned role as the international supreme court. Rather the problem is not so much improving the World Court, but understanding the merits of maintaining the status quo, that is, a decentralised judiciary.
\end{abstract}

\section{Keywords}

international judicial hierarchy - decentralised judiciary - judicial legitimacy

\section{Introduction}

Decided in 1953, Brown v. Allen ${ }^{1}$ empowers the federal courts of the United States to review de novo in a habeas corpus proceeding state convictions.

1344 U.S. 443 (1953). 
Concurring with the majority but only in the result, Associate Justice Robert H.Jackson advocated a more deferential treatment towards state courts. In his view, whenever decisions of one court are reviewed by another, a fraction of them would certainly be reversed. However, he was quick to clarify that any reversal by a superior court does not necessarily enhance the likelihood of justice being served, but merely reflects a difference in outlook normally found between judges of different courts. Hence, his perception of the highest judicial office is rather modest. As his aphorism goes, the supreme court is not final because it is infallible, but it is infallible only because it is final.

The same dilemma pervades international law. To begin with, no hierarchy exists between international courts and tribunals. ${ }^{2}$ This lack of a structured and vertical relationship has become more complex with the multiplication of international adjudicative fora in the last three decades. ${ }^{3}$ For scholars this development is disturbing as it increases the risks of jurisdictional or decisional overlaps, resulting in conflicts of jurisdiction or contradiction in decisions. ${ }^{4}$ To mitigate these risks, two former presidents of the International Court of Justice (ICJ) have called for the expanded advisory jurisdiction of the UN's principal judicial organ over doubtful or important points of general international law raised in cases before other international courts and tribunals. ${ }^{5}$

This article seeks to revisit the merits of this proposal in a broader context and proffers a descriptive account of the current international legal order rather than a normative theory of what international dispute settlement could or ought to be. Against this backdrop, the article addresses two questions. The first is whether the ICJ can be regarded as the "invisible" international supreme court. Answering this query in the negative, the first half of the article focuses

2 Chiara Giorgetti, "Horizontal and Vertical Relationships of International Courts and Tribunals - How Do We Address Their Competing Jurisdiction?," 30 ICSID Review (2015), 98, 99 .

3 Karin Oellers-Frahm, "Multiplication of International Courts and Tribunals and Conflicting Jurisdiction - Problems and Possible Solutions," 5 Max Planck Yearbook of United Nations Law (2001), 67, 70 .

4 Ram Prakash Anand, "Enhancing the Acceptability of Compulsory Procedures of International Dispute Settlement," 5 Max Planck Yearbook of United Nations Law (2001), 1, 4.

5 H.E. Judge Gilbert Guillaume, "The Proliferation of International Judicial Bodies: The Outlook for the International Legal Order" (Report of the ICJ to the Sixth Committee of the UN General Assembly, 26 October 2000); H.E. Judge Stephen Schwebel (Report of the ICJ to the Sixth Committee of the UN General Assembly, 26 October 1999), UN Doc. No. A/54/ PV.39. 
on the legitimacy of the ICJ. ${ }^{6}$ In particular, Part 2 zeroes in on the sociological aspect and identifies the extrinsic or political constraints by which States repudiate its proceedings and judgments, nipping in the bud any illusion of judicial supremacy by the ICJ on the international plane. On the other hand, Part 3 examines the intrinsic or institutional constraints, preventing ICJ decisions from attaining their full doctrinal value as a source of law and eventually weakening the normative legitimacy of the judicial institution.

Building upon the ICJ's lack of sociological and normative legitimacy for it to be regarded as the "invisible" international supreme court, the second half of the article addresses the second question, that is, whether the horizontal framework of international courts and tribunals is preferable over a hierarchical structure. In this regard, Part 4 lays down the legal underpinnings of a decentralised judiciary based on the current framework of international law, while Part 5 explores the consequences of this horizontal order and how it actually contributes to dispute settlement and the progressive development of international law.

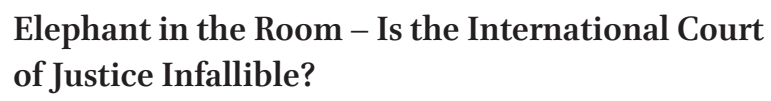

From a sociological standpoint, legitimacy derives from perceptions or beliefs concerning the right of an institution to rule. ${ }^{7}$ As a result, it may fluctuate over time and vary by the constituency or audience whose support is being measured. ${ }^{8}$ Unfortunately for the ICJ, its sociological legitimacy is at the mercy of States, who when antagonized, are free to repudiate the ICJ's discharge of its judicial function.

\subsection{Extrinsic Constraints}

States express their displeasure with the ICJ in at least five different ways. The first is their non-participation in the proceedings. States either refuse to submit a formal written or oral statement or choose not to appoint an agent. ${ }^{9}$

6 Harlan Grant Cohen, Andreas Follesdal, Nienke Grossman and Geir Ulfstein, "Legitimacy and International Courts - A Framework," in N. Grossman, H.G. Cohen, A. Follesdal and G. Ulfstein (eds.), Legitimacy and International Courts (2018), 1, 4.

7 Ibid.

8 Ibid.

9 James D. Fry, "Non-Participation in the International Court of Justice Revisited: Change or Plus Ça Change," 49 Columbia Journal of Transnational Law (2010), 35, 43. 
To name but a few cases where this has occurred, completely non-appearing respondents refused to appoint an agent in the Aegean Sea, ${ }^{10}$ Tehran Hostages, ${ }^{11}$ and Fisheries Jurisdiction cases. ${ }^{12}$ More provocatively, a non-participating State maintains an appearance of not fully cooperating. A case in point is the refusal of France's representatives to wear counsel's robes during the Nuclear Tests ${ }^{13}$ hearings before a full bench wearing its robes. ${ }^{14}$ Indeed, regardless of the degree of defiance, all refusals to abide by behavioral norms during proceedings manifest considerable disrespect for the ICJ as a venue for inter-State international adjudication. ${ }^{15}$

Second, because the ICJ lacks an enforcement mechanism of its own, compliance with its decisions is subject to the political will of States. As Judge Shigeru Oda warned in Armed Activities on the Territory of the Congo, "the repeated disregard of the judgments or orders of the Court by the parties will inevitably impair the dignity of the Court and raise doubts as to the judicial role to be played by the Court in the international community."17 What's more, under Article 94(2) of the UN Charter the entity responsible for ensuring compliance with the ICJ's decisions is not the ICJ, but the principal political organ for maintaining peace and security - the Security Council. In other words, "the enforcement of ICJ judgments involves quintessentially political acts by both parties and the Security Council, in which the Court itself has little involvement and over which it has no power."18

The third is the election of judges. The best example is the aftermath of the South West Africa case, ${ }^{19}$ a remarkable volte-face by the ICJ on an almost identical procedural, adjectival law ground only four years earlier. The triennial elections to the Court in the autumn of 1966 brought the unexpected defeat of candidates who were being "punished" for their respective State's vote. ${ }^{20}$

\footnotetext{
10 Aegean Sea Continental Shelf, Judgment, I.C.J. Reports 1978, p. 3.

11 United States Diplomatic and Consular Staff in Tehran, Judgment, I.C.J. Reports 1980, p. 3.

12 Fisheries Jurisdiction (United Kingdom v. Iceland), Merits, Judgment, I.C.J. Reports 1974, p. 3.

13 Nuclear Tests (New Zealand v. France), Judgment, I.C.J. Reports 1974, p. 457.

14 Fry, supra note 9, at 60.

15 Ibid., p. 47.

16 Armed Activities on the Territory of the Congo (Democratic Republic of the Congo v. Uganda), Provisional Measures, Order of 1 July 200o, I.C.J. Reports 200o, p. 111.

Ibid., p. 132 (Judge Oda, Declaration).

18 Aloysius P. Llamzon, "Jurisdiction and Compliance in Recent Decisions of the International Court of Justice," 18 European Journal of International Law (2007), 815, 822.

19 South West Africa, Second Phase, Judgment, I.C.J. Reports 1966, p. 6.

20 Edward McWhinney, "The International Court of Justice and International Law-Making: The Judicial Activism/Self-Restraint Antinomy," 5 Chinese Journal of International Law (2007), 3, 11 .
} 
Moreover, while the judicial post for President is traditionally a ceremonial post that is rotated every three years on a "regional" basis, the 1967 and 1970 elections were marked by an unusual degree of personal bitterness and ended in the defeat of "classical" candidates of some considerable seniority in favour of those considered more open, as jurists, to the winds of political change. ${ }^{21}$

Fourth, and perhaps the ultimate political constraint, is the subsequent withdrawal from the compulsory jurisdiction of the ICJ. ${ }^{22}$ The decisions by France and the United States to exit the optional-clause regime of the ICJ after adverse decisions in the Nuclear Tests and Nicaragua cases ${ }^{23}$ are two classic examples. ${ }^{24}$ The sudden turnaround of the ICJ in South West Africa similarly led to an effective boycott of the ICJ's jurisdiction by newly decolonized States who perceived the ICJ as an allegedly biased, "colonialist" tribunal. ${ }^{25}$

States can also repudiate judicial pronouncements outside the ICJ framework. To illustrate, in Lotus, ${ }^{26}$ the Permanent Court of International Justice (PCIJ) allowed Turkish authorities to prosecute a French captain whose boat struck a Turkish vessel on the high seas. However, because this rule of extraterritorial jurisdiction did not serve State interests, the judicial pronouncement was eventually rejected in a subsequent treaty. ${ }^{27}$ To be precise, Article 6(1) of the Convention on the High Seas granted exclusive jurisdiction to the flag State over ships sailing the high seas.

\section{$2.2 \quad$ Impact on Dispute Settlement}

Amidst these political constraints, the ICJ arguably still enjoys a certain level of deference from States. Nicaragua is a perfect example of a bold decision by the ICJ against high political stakes, but it "seem[s] to have matured with age and have come to be accepted notwithstanding initial criticism." ${ }^{28}$ Furthermore, not every unfavourable decision automatically leads to a withdrawal from

\footnotetext{
$21 \quad$ Ibid.

22 Tom Ginsburg, "Bounded Discretion in International Judicial Lawmaking," 45 Virginia Journal of International Law (2004), 631, 658 .

23 Military and Paramilitary Activities in and against Nicaragua (Nicaragua v. United States of America), Merits, Judgment, I.C.J. Reports 1986, p. 14.

24 Ginsburg, supra note 22, at $65^{8}$.

25 McWhinney, supra note 20, at 10.

26 Case of the S.S. Lotus (France v. Turkey), Judgment No. 9, 1927, P.C.I.J., Series A, No. 10.

27 Ginsburg, supra note 22, at 646.

28 Christian J. Tams, "The ICJ as a 'Law-Formative Agency': Summary and Synthesis," in C.J. Tams and J. Sloan (eds.), The Development of International Law by the International Court of Justice (2013), 377, 379.
} 
the compulsory jurisdiction of the ICJ. ${ }^{29}$ In fact, in the view of ICJ President Abdulqawi Ahmed Yusuf, "Compliance with the Court's judgments is not only satisfactory, but nearly total, even though there might exist certain delays." ${ }^{30}$

Then again, even with this positive outlook, the political pressure from States remains a viable threat affecting the ICJ's discharge of its judicial function. One profound consequence is the avoidance of political disputes. In this regard, a common strategy employed by the ICJ is declining jurisdiction on the basis of preliminary objections. ${ }^{31}$ By way of example, in Marshall Islands, ${ }^{32}$ the ICJ upheld the objection raised by the United Kingdom that there was no dispute, thereby shielding the ICJ from being drawn into the politically sensitive issue relating to nuclear weapons. An alternative avoidance strategy is to exercise jurisdiction but to adjudicate in a way that sidesteps the most politically sensitive issues. ${ }^{33}$ The Kosovo Advisory Opinion, ${ }^{34}$ for instance, has been criticized for doing just this. While the ICJ found that it had jurisdiction over the request, the ICJ skirted the core issue of the dispute, namely Kosovo's right to self-determination. ${ }^{35}$

Another ramification of the political backlash from States is the tendency of the ICJ to render Solomonic judgments. ${ }^{36}$ Perhaps this is another technique by which the ICJ avoids entering a final judgment that is likely to be disobeyed. This might explain why in Bosnian Genocide ${ }^{37}$ the ICJ appears to have been

29 Niels Petersen, "The International Court of Justice and the Judicial Politics of Identifying Customary International Law," 28 European Journal of International Law (2017), 357, 364.

3o H.E. Judge Abdulqawi Ahmed Yusuf, "The Strengths and Challenges for Supranational Justice: The Growing Role of the International Court of Justice" (Speech before the Royal Academy of Belgium, 12 November 2018), p. 5 .

31 Jed Odermatt, "Patterns of Avoidance: Political Questions Before International Courts," 14 International Journal of Law in Context (2018), 221, 227, 231.

32 Obligations concerning Negotiations relating to Cessation of the Nuclear Arms Race and to Nuclear Disarmament (Marshall Islands v. United Kingdom), Preliminary Objections, Judgment, I.C.J. Reports 2016, p. 833 .

33 Odermatt, supra note 31, at 233.

34 Accordance with International Law of the Unilateral Declaration of Independence in Respect of Kosovo, Advisory Opinion, I.C.J. Reports 2010, p. 403.

35 Odermatt, supra note 31, at 233.

36 Nienke Grossman, "Solomonic Judgments and the Legitimacy of the International Court of Justice," in N. Grossman, H.G. Cohen, A. Follesdal and G. Ulfstein (eds.), Legitimacy and International Courts (2018), 43-61.

37 Application of the Convention on the Prevention and Punishment of the Crime of Genocide (Bosnia and Herzegovina v. Serbia and Montenegro), Judgment, I.C.J. Reports 2007, p. 43. 
overly lenient towards Serbia, ${ }^{38}$ why in Oil Platforms ${ }^{39}$ neither side actually won what it asked for (but also neither side totally lost), ${ }^{40}$ or why in Peru $v$. Chile $^{41}$ rather than adopting the position of one of the parties - either an agreement existed reaching to 200 nautical miles or there was no agreement the ICJ split the pie between Peru and Chile. ${ }^{42}$

\section{Unraveling the Paradox - the Doctrine of Finality under the Statute of the International Court of Justice and in Practice}

In contrast to sociological legitimacy, normative legitimacy is prescriptive and concerns the right to rule according to predefined standards such as the effectiveness of the institution to carry out its mandate. ${ }^{43}$ As regards the ICJ, albeit Article 38(1) of the ICJ Statute sets forth that its function is "to decide in accordance with international law such disputes as are submitted to it," the prevailing view interprets the mandate of international courts and tribunals as going beyond dispute settlement and including the development of international law. ${ }^{44}$ Measured against this broader function, and as will be shown, the ICJ suffers from institutional constraints preventing its decisions from realizing their full doctrinal value as a source of law outside of the confines of the dispute.

38 Vojin Dimitrijevic and Marko Milanovic, "The Strange Story of the Bosnian Genocide Case," 21 Leiden Journal of International Law (2008), 65, 85.

39 Oil Platforms (Islamic Republic of Iran v. United States of America), Judgment, I.C.J. Reports 2003, p. 161.

40 Lori Fisler Damrosch, "The Impact of the Nicaragua Case on the Court and Its Role: Harmful, Helpful or in Between?," 25 Leiden Journal of International Law (2012), 135, 144.

41 Maritime Dispute (Peru v. Chile), Judgment, I.C.J. Reports 2014, p. 3.

42 Grossman, supra note 36 , at 51.

43 Cohen et al., supra note 6, at 4, 8-9.

44 Armin von Bogdandy and Ingo Venzke, "On the Functions of International Courts: An Appraisal in Light of Their Burgeoning Public Authority," 26 Leiden Journal of International Law (2013), 49, 55-57; José E. Alvarez, "What are International Judges for? The Main Functions of International Adjudication," in C.P.R. Romano, K.J. Alter and Y. Shany (eds.), Oxford Handbook of International Adjudication (2013), 159, 168-170; Yaël Ronen, "Functions and Access," in W.A. Schabas and S. Murphy (eds.), Research Handbook on International Courts and Tribunals (2017), 463, 467-469; Chester Brown, "The Inherent Powers of International Courts and Tribunals," 76 British Yearbook of International Law (2015), 195, 232-235. 


\subsection{Intrinsic Constraints}

To begin with, under Article 59 of the ICJ Statute, decisions by the ICJ do not enjoy stare decisis value. In fact, based on the debate in the Committee of Jurists, the purpose of Article 59 is precisely to rule out a system of binding precedent. ${ }^{45}$ While the ICJ cites in practice its prior pronouncements, the fact remains that it remains free to depart from them. A perfect illustration of this is maritime delimitation. Indeed the law has been in a state of flux for quite some time between the equidistance method on the one hand, and the application of equitable principles or the search for equitable results on the other. ${ }^{46}$ At times the departure is subtler, as when the ICJ cites the development of obligations erga omnes in Barcelona Traction, ${ }^{47}$ tacitly reversing South West Africa, Second Phase where standing was denied to Liberia and Ethiopia for lack of a legal interest. ${ }^{48}$ The application of Article 62 of the ICJ Statute also illustrates an implicit deviation from earlier rulings concerning the jurisdictional-link requirement in third-party interventions. ${ }^{49}$ In other words, and as aptly put by Professor Alain Pellet, decisions of the ICJ, by themselves and individually taken, are at best a source of obligation for the disputing parties, but not a source of law for third parties. ${ }^{50}$

Another institutional constraint is the principle of res judicata. Depending on the type of proceeding involved, the ICJ seems to have diametrically opposed conceptions of the same principle. To be precise when the proceeding concerns Article 60 of the ICJ Statute, res judicata is narrowly construed so as to cover only the dispositif and the motifs inseparable from or essential to the dispositif. This was the doctrine adopted by the ICJ in the interpretation of the Temple of Preah Vihear ${ }^{51}$ judgment. However, when confronted with the res judicata effect of a prior decision on a proceeding under Article 36 of the ICJ Statute, the principle is broadly applied as to include all the motifs as well. In Bosnian Genocide, ${ }^{52}$ for example, the majority was of the view that

45 James R. Crawford, Brownlie's Principles of Public International Law (2015), 38.

46 Gilbert Guillaume, "The Use of Precedent by International Judges and Arbitrators," 2 Journal of International Dispute Settlement (2011), 5, 11.

47 Barcelona Traction, Light and Power Company, Limited, Judgment, I.C.J. Reports 1970, p. 3, at 32 .

48 Crawford, supra note 45 , fn. 125 .

49 Oellers-Frahm, supra note 3 , fn. 26.

5o Alain Pellet, "Decisions of the ICJ as Sources of International Law?," 2 Gaetano Morelli Lectures Series (2018), 7, 23.

51 Request for Interpretation of the Judgment of 15 June 1962 in the Case concerning the Temple of Preah Vihear (Cambodia $v$. Thailand) (Cambodia v. Thailand), Judgment, I.C.J. Reports 2013, p. 281.

$5^{2} \quad$ Bosnian Genocide, supra note 37, at 98-99. 
the 1996 Judgment on the preliminary objections constituted res judicata "as a matter of logical construction" on the issue of Serbia's standing before the ICJ. Simply put, here lies the irony. For the purpose of Article 60 of the ICJ Statute, the object of interpretation must be narrow because the broader the understanding of what constitutes res judicata, the more of the original judgment can be considered again and the more of what should be interpretation turns into reconsideration. ${ }^{53}$ In contrast, if the ultimate goal were the avoidance of re-litigation of identical or similar disputes, the scope of res judicata, when considered in subsequent but original judgments, must be broad because the more the earlier judgment is regarded as final and binding, the less the issue can be re-litigated. ${ }^{4}$ These divergent conceptions of the same principle certainly do not augur well for the stability of judgments, considering that the issue of res judicata may arise in consecutive proceedings, first under Article 6o, and then under Article 36 of the ICJ Statute. ${ }^{55}$

The third institutional constraint is Article 34(1) of the ICJ Statute, limiting to States the only entities who can appear before the ICJ. To be sure, this State-centric competence restricts the ability of the ICJ in directly and fully enunciating doctrinal pronouncements in investor-State disputes, human rights cases initiated by individuals and cases involving international organizations. ${ }^{56}$ As ICJ Judge James Crawford quickly points out, whereas the European Union appears before the wTO dispute settlement body as a matter of course and has been a party to disputes before other fora such as the ITLOS and Annex-VII arbitration proceedings, it cannot appear in contentious proceedings before the ICJ ${ }^{57}$ Related to this institutional constraint is the limited scope of the compulsory jurisdiction of the ICJ. As of 1 January 2018, only 73 out of 193 UN Member States have deposited their optional-clause declarations. ${ }^{58}$

53 Andreas Kulick, "Article 6o ICJ Statute, Interpretation Proceedings and the Competing Concepts of Res Judicata," 28 Leiden Journal of International Law (2015), 73, 87.

54 Ibid., p. 86.

55 Ibid., p. 87.

56 James Crawford, "The Place of the International Court in International Dispute Settlement," in J. Crawford, A. Koroma, S. Mahmoudi and A. Pellet (eds.), The International Legal Order: Current Needs and Possible Responses, Essays in Honour of Djamchid Momtaz (2017), 95, 107 .

$57 \quad$ Ibid.

$5^{8}$ "States Entitled to Appear before the Court," ICJ-CIJ.org, https://www.icj-cij.org/en/ states-entitled-to-appear (last visited 20 February 2019). 
This means that only $37.8 \%$ of the parties to the ICJ Statute recognize the compulsory jurisdiction of the ICJ. More importantly, only the United Kingdom among the five Security Council members continues to accept the compulsory jurisdiction of the ICJ, and even then, its optional-clause declaration is filled with reservations in reaction to every case brought against it.

Collectively, these institutional constraints endanger in three ways the capacity of the ICJ to fulfill its broader mandate of contributing to the development of international law. First, by the inapplicability of the doctrine of stare decisis, judicial decisions of the ICJ, individually envisaged, only serve as a source of obligation for the disputing parties, but not necessarily a formal source of law for third parties. Second, even when the decisions of the ICJ can potentially be a source of law when collectively and cumulatively taken, the ICJ's fluid application of the principle of res judicata, ranging from narrow to broad depending on the type of proceeding instituted, renders uncertain which part of the decision is actually binding. Third, by reason of the Statecentric competence of the ICJ and its limited compulsory jurisdiction, the normative strength of its decisions is limited to inter-State relations and further reduced to a select number of States willing to be bound by its judicial pronouncements. As a result, these institutional constraints weaken in turn the normative legitimacy of the ICJ inasmuch as its decisions are gradually stripped of their full doctrinal value.

\subsection{Impact on the Development of International Law}

If the political constraints from States affect dispute settlement, by contrast, the institutional constraints on the ICJ strongly impact the development of international law.

To begin with, the ICJ's relevance as a judicial body depends on the number of cases brought before it and the significance of those cases in raising new and contested legal issues. ${ }^{59}$ As a result, the significant contributions of the ICJ typically concern areas on which it has had the opportunity to pronounce regularly or repeatedly. ${ }^{60}$ The result is the "differentiated" influence of the ICJ on the different areas of international law. ${ }^{61}$ The importance of PCIJ and ICJ decisions on the development of treaty law and the law of responsibility reflects the fact that, because the topics cross-cut a wide range of subjects, they arise in a large portion of the cases. ${ }^{62}$ In fact, Judge Crawford considers State

\footnotetext{
59 See Alan Boyle and Christine Chinkin, The Making of International Law (2007), 269.

6o Tams, supra note 28 , at 392.

$61 \quad$ Ibid.

62 Ibid.
} 
responsibility as one of the issues the ICJ engages with the most and that it actually makes up approximately one-third of its docket. ${ }^{63}$ By the same token, the ICJ could be expected to become an "authoritative guide" in territorial and boundary disputes, just as it has had the opportunity to address and revisit relevant aspects of the jus ad bellum and the legal regime governing diplomatic protection..$^{64}$

By contrast, it is very difficult to see how the ICJ could have shaped areas of law that it has had the occasion to address in only a handful of cases - as is the case with international humanitarian law, immunities, or human rights or international environmental law. ${ }^{65}$ Finally, the virtual disappearance of the ICJ from debates about minority protection (an area shaped in important ways by its predecessor) can be taken to reflect the shift from a heavily judicialised system, involving the regular involvement by the PCIJ in contentious or advisory proceedings, to a minority protection regime that is partly integrated into human rights protection and that partly avoids recourse to binding dispute settlement. ${ }^{66}$

\section{The Road Less Taken - A Decentralised Judiciary and} Its Legal Bases

To clarify, while the ICJ may suffer from lack of legitimacy due to extrinsic and intrinsic constraints, this does not mean rectifying them for the purpose of enabling the ICJ to be the envisioned international supreme court. In fact, some of these political and institutional constraints can also be found in other international courts and tribunals. However, the problem is not so much rectifying these perceived flaws as it is understanding the merits of maintaining the status quo, that is, a decentralised judiciary.

\subsection{Interpretation of International Law as a Shared Judicial Function}

Under Article 38(1)(d) of the ICJ Statute judicial decisions are a subsidiary means for the determination of rules of law. Noticeably, the phrase judicial decisions is used in its generic sense and does not refer to a particular court or

63 James Crawford, "The International Court of Justice and the Law of State Responsibility," in C.J. Tams and J. Sloan (eds.), The Development of International Law by the International Court of Justice (2013), 72, 85 .

64 Tams, supra note 28 , at 392.

65 Ibid.

66 Ibid. pp. 392-393. 
tribunal, and not even to the ICJ. ${ }^{67}$ In other words, the interpretation of international law is a shared mandate of all international courts and tribunals. No adjudicative body has a monopoly over this authority.

Albeit the ICJ is the principal judicial organ of the UN and all UN Member States are ipso facto parties to the ICJ Statute, the ICJ does not have automatic compulsory jurisdiction over all international legal disputes. ${ }^{68}$ It is neither a court of appeal from other international tribunals, and much less do its judgments enjoy a superior status. ${ }^{69}$ Furthermore, the ICJ has no power to ensure any systematic coherence between the judgments of different international courts and tribunals..$^{70}$ As aptly put by Professors Alan Boyle and Christine Chinkin, "Constitutionally it is simply one court among many."71

With the lack of legislature on the international plane, the development of international law by international courts and tribunals cannot be overemphasized. ${ }^{72}$ As Judge Gerald Fitzmaurice succinctly puts it in his separate opinion in Barcelona Traction, "since specific legislative action with direct binding effect is not at present possible in the international legal field, judicial pronouncements of one kind or another constitute the principal method by which the law can find some concrete measure of clarification and development."73 Judge Fitzmaurice also concurs with Sir Hersch Lauterpacht that the clarification and development of the law is "incumbent" upon international tribunals, placing them in a different position from their domestic counterparts. ${ }^{74}$

The role of international courts and tribunals must also be appreciated in the context of international law as a process rather than as rules. As former ICJ President Rosalyn Higgins postulates, "international law is a continuing process of authoritative decisions." ${ }^{\text {" }}$ It is not the mere impartial application of rules, but the entire decision-making process itself. ${ }^{76}$ Higgins echoes the view of Lauterpacht that the judge does not "find rules" but "makes choices" and choices "not between claims which are fully justified and claims which have

67 Anthea Roberts and Sandesh Sivakumaran, "The Theory and Reality of the Sources of International Law," in M. Evans (ed.), International Law (5th edition, 2018), 89, 99.

68 Boyle and Chinkin, supra note 59 , at 263.

69 Ibid.

$70 \quad$ Ibid.

$71 \quad$ Ibid.

72 Vitalius Tumonis, "Adjudication Fallacies: The Role of International Courts in Interstate Dispute Settlement," 35 Wisconsin International Law Journal (2013), 31, 62, fn. 100.

73 Barcelona Traction, supra note 47, at 64 (Judge Fitzmaurice, Separate Opinion).

74 Ibid.

75 Rosalyn Higgins, Problems and Process: International Law and How We Use It (2015), 2.

76 Ibid. 
no foundation at all but between claims which have varying degrees of legal merit."77 Consistent with this perspective, the interpretation of international law must also be viewed as a responsibility co-equally shared by all pre-constituted courts and ad hoc tribunals. No one can be superior over the other because each adjudicative body is a participant in the law-making process.

More fundamentally, a decentralised judiciary finds its basis in the tenets of justice. According to Judge Thomas Buergenthal, "The function of a judge in any jurisdiction is in his or her quest for, and realization of, 'justice' in the context of a concrete case." 78 In addition to being a personal assessment of the judges, the meaning of justice in the international context is further embedded within three different layers of difficulty. These include (1) identifying justice in the context of pluralistic values in society, (2) applying justice in the context of tension between justice and stability, and (3) characterizing justice in the context of the dichotomy between justice in human terms and justice in sovereign terms. ${ }^{79}$ Judge Buergenthal then adds that this is the situation that the ICJ constantly encounters - a collegial body trying to reach a uniform view on achieving justice amidst divergent assessments on the matter. ${ }^{80}$ This dynamic might work within the confines of the UN, considering that the ICJ is one of its organs. However, how the ICJ views justice may not be extended anywhere else. Precisely no court or tribunal can ever impose its ideals of justice on another adjudicative body for as long as international law remains horizontally structured and the community of nations has pluralistic rather than universal values.

\subsection{Respect for State Sovereignty}

As a general principle of law, States are sovereign and equal. ${ }^{81}$ As a result, no State, large or small, would consider itself bound by rules to which it has not consented. $^{82}$ The same principle applies to international dispute settlement. Albeit Article 2(3) of the UN Charter enshrines the duty to settle international disputes through peaceful means, States cannot be dragged off to third-party adjudication without their consent.

\footnotetext{
$77 \quad$ Ibid. p. 3 .

78 Thomas Buergenthal, "Lawmaking by the ICJ and Other International Courts," 103 American Society of International Law Proceedings (2009), 397, 402.

79 Ibid.

$80 \quad$ Ibid.

81 UN Charter, Art. 2(1).

82 Juliane Kokott, "States, Sovereign Equality," Max Planck Encyclopedia of Public International Law (last visited 21 February 2019).
} 
The idea of establishing a binding system to resolve international disputes is indeed attractive, but only in theory ${ }^{83}$ In reality, as soon as such arrangements for compulsory jurisdiction are established, States realize the risks of committing to litigation and begin to have second thoughts. ${ }^{84}$ The result is a reluctance to subscribe to the more general arrangements for compulsory jurisdiction and a preference for more flexible agreements that accommodate particular types of cases or individual disputes. ${ }^{85}$

As scholars are quick to point out, States remain stubbornly attached to what they perceive as their domaine réservé, making them highly resistant to any third-party "interference" with the exercise of their sovereign prerogatives. ${ }^{86}$ While a decentralised judiciary may appear somewhat anarchic, the lack of a rigid structure among courts and tribunals is built precisely on the cornerstone of modern international law - the principle of State sovereignty.

In addition to finding a basis in law, a decentralised judiciary has a practical significance as well. To be precise, the horizontal relationship among adjudicative bodies amidst their perceived proliferation contributes to the development of the judicial function, transforming international courts and tribunals into relevant legal actors in international law.

\subsection{Expansion of Judicial Function}

Addressing the Sixth Committee of the UN General Assembly about the perceived proliferation of international judicial bodies, former ICJ President Gilbert Guillaume noted two parallel developments in the second half of the twentieth century. ${ }^{87}$ On the one hand, States interact with one another more frequently and with increased diversity. On the other hand, non-State actors like corporations, non-governmental organizations and private individuals have at the same time become preoccupied with transnational activities.

\footnotetext{
83 John G. Merrills, International Dispute Settlement (2017), 311.

84 Ibid.

85 Ibid.

86 Sir Arthur Watts, "Enhancing the Effectiveness of Procedures of International Dispute Settlement," 5 Max Planck Yearbook of United Nations Law (2001), 21, 23; Eric De Brabandere, "Non-State Actors and the Individualization and Proliferation of International Dispute Settlement," in Bob Reinalda (ed.), The Ashgate Research Companion to Non-State Actors (2011), 347 .

87 Guillaume, supra note 5 , at 2.
} 
According to Judge Guillaume, "This dual expansion in inter-State relations and cross-frontier transactions [...] has inevitably rendered it necessary, if not essential, to make all these relationships subject to the rule of law." 88 The result is the emergence of new areas of international law and the advent of new participants, particularly non-State actors. The creation of courts and ad hoc tribunals who are not answerable to any superior judicial body is an adaptation to these fundamental changes.

To be sure, the diversification of the legal domains in the international sphere has rendered international law more complex and more heterogenous. To the extent that these new areas call for the application of specific legal rules, greater in-depth knowledge of science or economics may be required. Further, more sensitivity to specific local conditions may also prove equally important. This degree of expertise and familiarity with a particular custom or tradition can only be addressed by judicial bodies created at will and by agreement between States.

\subsection{Enhancement of Judicial Function}

A decentralised judiciary also enhances the judicial function in two ways, namely by putting in an internal system of checks and balances and by strengthening legal reasoning through judicial cross-fertilisation.

\subsubsection{Through Internal Checks and Balances}

One obvious danger of a judicial hierarchy among international courts and tribunals is the finality and superiority of the pronouncements by the "international supreme court." The question then becomes - who guards the guardian? In the case of the ICJ, for example, one scholar describes it as the "reluctant guardian" because of the ICJ's minimalist and cautious interpretation of peremptory norms and obligations erga omnes. ${ }^{89}$ Another challenge to the ICJ is the identification of custom, which according to one commentator is subject to the judicial politics of the ICJ. ${ }^{90}$

Admittedly, every court or tribunal cannot be completely shielded from political biases or pressure. However, putting one body at the apex of the judicial hierarchy is certainly not the ideal solution because this would mean subjecting the entire judicial framework to the political and institutional limitations of that lone supreme body. A decentralised judiciary, by contrast,

\footnotetext{
$88 \quad$ Ibid.

89 Gleider I. Hernandez, "A Reluctant Guardian: The International Court of Justice and the Concept of 'International Community', 83 British Yearbook of International Law (2013), 13.

9o Petersen, supra note 29, at 357.
} 
prevents this. Precisely, a horizontal relationship among courts and tribunals endows them with autonomy, allowing them to check on one another and fill in the gaps left by one judicial body. For example, while the ICJ is seen to have refrained from subjecting UN Security Council resolutions to judicial review, the International Criminal Tribunal for the former Yugoslavia (ICTY) at least reviewed the legality of the resolution to which it owes its existence. ${ }^{91}$ In other words, while the classic debate between effective control in Nicaragua and overall control in Tadic appears to highlight the inconsistency in decisionmaking, this tension actually shows how a decentralised judiciary is preferable over one that is hierarchical because of the checks-and-balances mechanism inherently in place.

\subsubsection{Through Judicial Cross-Fertilisation}

The practice of international courts also indicates that they increasingly cite not only their own decisions but also judgments of their sister institutions. While obviously not binding precedents as between them, these decisions are treated as persuasive authority. For example, the ICJ cites decisions of the ICTY in Bosnian Genocide in much the same way that the Inter-American Court of Human Rights draws on decisions of the European Court of Human Rights and those of the ICJ. Similar practice can be observed from inter-State and investor-State arbitrations.

For Judge Buergenthal, this is what he considers "international judicial cross-fertilization." ${ }^{92}$ Presumably, this emerging practice of cross-referencing among international courts and tribunals is attributable to the integrative potential of Article 38(1)(d) of the ICJ Statute. By acknowledging "judicial decisions $[\ldots]$ as a subsidiary means for the determination of rules of law," Article $38(1)$ (d) "offers a basic communicative framework for the "production of communitarian semantics' that allows for the development of an international judicial system. ${ }^{\prime 93}$ Indeed, with the apparent increase in the number of judicial and arbitral bodies also comes a greater number of international judges

91 Von Bogdandy and Venzke, supra note 44, at 58.

92 Buergenthal, supra note 78 , at 405 .

93 Mads Andenas and Johann Ruben Leiss, “The Systematic Relevance of 'Judicial Decisions' in Article 38 of the ICJ Statute," 77 Heidelberg Journal of International Law (2017), 907, 908. 
and arbitrators whose pronouncements may contribute to the corpus of international law. ${ }^{94}$ Hence to the extent that the continued multiplication of courts and tribunals permits greater law-making creativity within the international judicial system and by courts constituting that system, a decentralised judiciary is likely to strengthen international law. ${ }^{95}$

\subsection{Evolution of Judicial Function}

Finally, a decentralised judiciary has transformed the judicial mandate of courts and tribunals into a multi-faceted function.

Traditionally, courts and tribunals are perceived as venues for dispute settlement. However, with the continued creation of adjudicative fora, this is no longer the case. The second half of the twentieth century has witnessed not only a quantitative development of dispute settlement bodies, but also a qualitative expansion and transformation of the nature and competence of those bodies, which are not only aimed at the settlement of disputes but also at ensuring and monitoring compliance with international law. ${ }^{96}$ Examples include regional human rights courts whose decisions reflect whether States comply with their human rights obligations. Another emergent judicial function is enforcement, as can be seen from the powers granted to ad hoc criminal tribunals and the International Criminal Court. ${ }^{97}$

\section{$6 \quad$ Conclusion}

Suffering from extrinsic and intrinsic constraints, the ICJ is neither infallible nor final. With the political tools at the disposal of States, the ICJ is significantly constrained from effectively discharging its judicial function. At the same time, the norm-setting character of ICJ decisions is subject to institutional constraints. Together, these restrictions endanger the legitimacy of the ICJ to be regarded as the "invisible" international supreme court.

94 Boyle and Chinkin, supra note 59 , at 265 .

95 Buergenthal, supra note 78 , at 405.

96 Oellers-Frahm, supra note 3 , at 69.

97 Dinah Shelton, "Form, Function and the Powers of International Courts," 9 Chicago Journal of International Law (2009), 537, 566. 
Be that as it may, this does not detract from the merits of maintaining the status quo. For one, a decentralised judiciary finds basis in Article $38(1)(d)$ of the ICJ Statute and, more importantly, in the principle of State sovereignty, the cornerstone of international law. On a more practical level, a decentralised judiciary is even better than one that is hierarchical, as it contributes to the growing importance and increasing relevance of the judicial function in the current framework of international law. 